\title{
EVALUASI KETERSEDIAAN SUMBER DAYA AIR BERBASIS METODE NERACA AIR THORNTHWAITE MATHER UNTUK PENDUGAAN SURPLUS DAN DEFISIT AIR DI PULAU JAWA
}

\author{
Anistia Malinda Hidayat*, Aryo Prasetyo Mulyo, Audia Azizah Azani, Diar Aofany, \\ Ricky Nadiansyah, Hasti Amrih Rejeki
}

\author{
Sekolah Tinggi Meteorologi Klimatologi dan Geofisika \\ Jl. Perhubungan I No. 5 Pondok Betung, Pondok Aren, Tangerang Selatan - Banten \\ *Email: anistia.malinda@gmail.com
}

\begin{abstract}
As a natural resource that is vital in supporting human life, the evaluation of the availability of water resources is an urgency in determining and projecting the condition of water surplus or deficit in a Wilayah. There are various methods in evaluating the availability of water resources in an area, one method that has a high level of significance is the Thornthwaite Mather water balance method. Water balance analysis was carried out in 3 Wilayahs in Java Island which have monsoonal rain types, including Bandung, Begawan Solo watershed, and Pasuruan. The results of the evaluation of the availability of water resources in Bandung show a surplus condition of water in the rainy season period and deficit in the dry season period. Meanwhile, the water balance analysis in Solo shows deficit conditions in all areas covered by the Bengawan Solo watershed. Water balance analysis in Pasuruan Regency shows the same pattern as the Bandung area, where there is a surplus condition in the rainy season and deficits in the dry season period. While the results of the projection of the availability of water resources show varying results in the three Wilayahs, where there is generally an increase in the number of Wilayahs experiencing water deficits. Based on these conditions, water conservation efforts need to be formulated, both by the community and the local government.
\end{abstract}

Keywords: water balance, Thornthwaite Mather, surplus, deficit, projection

\begin{abstract}
Abstrak: Sebagai sumber daya alam yang sangat vital dalam menunjang kehidupan manusia, evaluasi ketersediaan sumber daya air merupakan sebuah urgensi dalam menentukan serta memproyeksikan kondisi surplus atau defisit air di suatu wilayah. Terdapat berbagai metode dalam mengevaluasi ketersediaan sumber daya air di suatu wilayah, salah satu metode yang memiliki tingkat signifikansi tinggi adalah metode neraca air Thornthwaite Mather. Analisis neraca air dilakukan pada 3 wilayah di Pulau Jawa yang memiliki tipe hujan monsunal, meliputi Bandung, DAS Begawan Solo, dan Pasuruan. Hasil evaluasi ketersediaan sumber daya air di Bandung menunjukkan kondisi surplus air pada periode musim penghujan dan defisit pada periode musim kemarau. Sementara itu, analisis neraca air di Solo menunjukkan kondisi defisit pada seluruh area yang tercakup dalam DAS Bengawan Solo. Analisis neraca air di Kabupaten Pasuruan menunjukkan pola yang sama dengan wilayah Bandung, dimana terjadi kondisi surplus pada periode musim penghujan dan defisit pada periode musim kemarau. Sedangkan hasil proyeksi ketersediaan sumber daya air menunjukkan hasil yang bervariasi pada ketiga wilayah, dimana secara umum terjadi peningkatan jumlah wilayah yang mengalami defisit air. Berpijak pada kondisi tersebut, upaya-upaya konservasi air perlu segera dirumuskan, baik oleh masyarakat maupun pemerintah daerah setempat.
\end{abstract}

Kata kunci: neraca air, Thornthwaite Mather, surplus, defisit, proyeksi 


\section{PENDAhuluan}

Pertimbangan daya dukung lingkungan dalam penataan ruang merupakan amanah Undangundang Negara Republik Indonesia No. 26 Tahun 2007 tentang Penataan Ruang dan No. 32 Tahun 2009 tentang Pengelolaan Lingkungan Hidup. Sebagai salah satu pulau besar di Indonesia, Pulau Jawa memiliki kepadatan penduduk yang tinggi. Oleh karena itu, pulau ini memiliki peranan penting dalam sektor pembangunan sehingga membutuhkan dukungan sumber daya air yang cukup besar. Ditinjau dari kondisi topografi lahan, Pulau Jawa memiliki banyak Daerah Aliran Sungai (DAS). Setidaknya saat ini terdapat 16 daerah aliran sungai di Pulau Jawa yang berada dalam kondisi kritis. Hal tersebut dapat dilihat dari minimnya luasan tutupan lahan bervegetasi pada beberapa daerah DAS yang mencapai kurang dari 20\% (Mawardi, 2010). Kekritisan ini disebabkan oleh banyak hal seperti semakin padatnya jumlah penduduk di Pulau Jawa serta kebijakan pemanfaatan sumber daya alam yang tidak berprinsip pada pembangunan yang berkelanjutan (sustainability development).

Distribusi air berbeda-beda di setiap tempatnya bergantung pada kondisi klimatologis (evaporasi, angin, suhu udara, kelembaban udara, dan penyinaran matahari) serta kondisi lahan (DAS) seperti jenis tanah, tata guna lahan, kemiringan lahan, dan sebagainya. Pada suatu daerah bisa saja sumber daya airnya berlebih (surplus). Memungkinkan pula ada daerah yang mengalami kekurangan air (defisit). Agar dapat mengetahui ketersediaan sumber daya air pada suatu daerah, diperlukan sebuah perhitungan yang disebut dengan neraca air. Neraca air (water balance) merupakan perkiraan secara kuantitatif dari siklus hidrologi yang dinyatakan berdasarkan prinsip konservasi massa (Triatmodjo, 2008). Perhitungan ini dimaksudkan untuk mengevaluasi keluar-masuknya air dalam suatu sistem seperti daerah aliran sungai (DAS), waduk, danau, serta aliran permukaan.

Perhitungan neraca air ini digunakan untuk mengevaluasi ketersediaan air di Pulau Jawa serta menentukan kondisi suatu daerah mengalami defisit atau surplus. Penelitian ini dilakukan di 3 lokasi penelitian, yaitu kota Bandung, Solo, dan Pasuruan dengan asumsi bahwa ketiga daerah tersebut dapat menjadi gambaran kondisi ketersediaan air di masingmasing provinsi, yaitu Jawa Barat, Jawa Tengah, dan Jawa Timur. Ketiga lokasi penelitian ini sebelumnya pernah dikaji menggunakan perhitungan neraca air Thornthwaite Mather. Pengetahuan mengenai kondisi hidrologis di suatu wilayah dapat dijadikan sebagai referensi pembuatan perumusan untuk pengendalian air pada daerah-daerah surplus serta upaya-upaya untuk melakukan konservasi air pada wilayah-wilayah yang mengalami defisit. Tujuan dari penelitian ini adalah untuk mengevaluasi dan mengidentifikasi tingkat ketersediaan sumber daya air di lokasi penelitian dan sebagai proyeksi ketersedian sumber daya air di masa yang akan datang.

\section{METODE PENELITIAN}

\subsection{Domain Wilayah Penelitian}

Daerah penelitian berada di Pulau Jawa atau terletak pada $5^{0} \mathrm{LS}-10{ }^{0} \mathrm{LS}, 105^{\circ} \mathrm{BT}-$ $115^{\circ} \mathrm{BT}$. Berdasarkan pembagian iklim, seluruh wilayah Pulau Jawa memiliki tipe iklim monsunal (Aldrian dan Susanto, 2003), sehingga hujan di wilayah Jawa sangat dipengaruhi oleh aktivitas monsun. Penelitian ini difokuskan pada tiga wilayah di Pulau Jawa, yaitu Bandung yang terletak di Provinsi Jawa Barat (Fu'adah dkk, 2015), Daerah Aliran Sungai (DAS) Bengawan Solo Hulu yang terletak di Provinsi Jawa Tengah, dan wilayah Pasuruan yang terletak di Provinsi Jawa Timur (Bonita dan Mardyanto, 2015). Lingkup wilayah DAS Bengawan Solo masuk dalam 2 provinsi, yaitu Jawa Tengah (Kabupaten Wonogiri, 
Sukoharjo, Klaten, Karanganyar, Boyolali, dan Kota Surakarta), serta Kabupaten Ponorogo, Jawa Timur (Anna dkk, 2016).

\subsection{Metode Thornthwaite Mather}

Metode yang digunakan dalam penelitian ini adalah metode analisis deskriptif dengan mengkaji dan membandingkan beberapa jurnal terkait ketersediaan air tanah menggunakan metode perhitungan neraca air Thornthwaite Mather. Metode neraca air Thornthwaite Mather dapat digunakan untuk mengetahui kondisi air secara kuantitas dan limpasan (runoff) pada tiap bulannya pada satu tahun. Penelitian yang dilakukan oleh Calvo (1986) menunjukkan bahwa model Thornthwaite-Mather dapat digunakan untuk memprediksi aliran bulanan dengan tingkat signifikansinya (nilai R2-nya) relatif sama yaitu berkisar pada angka 90\%. Lebih lanjut, penelitian lain menunjukkan bahwa hasil simulasi debit bulanan di sub DAS Wuryantoro menggunakan metode Thornthwaite Mather memiliki korelasi yang tinggi dengan tingkat signifikasi yang berkisar antara 70 sampai 90\% (Pramono dan Adi, 2010). Berpijak pada penjelasan tersebut, penelitian ini menggunakan jenis metode neraca air Thornthwaite Mather untuk mengetahui kondisi ketersediaan air di Pulau Jawa. Perhitungan menggunakan metode Thornthwaite Mather mempertimbangkan rerata bulanan curah hujan dan indeks panas bulanan (Nasution dan Syaifullah, 2005; Pramono dan Adi, 2010; Fu'adah dkk, 2015; Bonita dan Mardyanto, 2015). Langkah-langkah perhitungan neraca air dengan metode Thornthwaite Mather secara runtut dijabarkan pada poin 2.2.1 sampai 2.2.3.

\subsubsection{Data Curah Hujan}

Data curah hujan yang digunakan dalam penelitian Fu'adah dkk (2015) di wilayah Bandung, yaitu data historis curah hujan bulanan pada tahun 2000-2009 (10 tahun) pada 12 titik stasiun pengamatan curah hujan yang mewakili wilayah Bandung. Data curah hujan yang digunakan pada penelitian di wilayah Kecamatan Kejayan, Kabupaten Pasuruan merupakan data curah hujan rata-rata bulanan pada tahun 2014 dengan jumlah curah hujan rata-ratanya per tahun mencapai 1513,67 mm/tahun (Bonita dan Mardyanto, 2015). Sedangkan pada DAS Begawan Solo diambil data curah hujan dari 9 sub-DAS Bengawan Solo Hulu pada tahun 2014 (Anna dkk., 2016).

\subsubsection{Data Suhu Udara Rata-rata Bulanan}

Data suhu udara didapatkan dari stasiun pengamatan dan dihitung rata-rata bulanannya. Namun jika stasiun lokasi penelitian tidak memiliki data suhu, maka dapat digunakan Persamaan Mock (1973) untuk menduga suhu dengan rumus sebagai berikut:

di mana :

$$
\Delta \mathrm{T}=0.006\left(\mathrm{z}_{1}-\mathrm{z}_{2}\right)
$$

$\Delta T=$ Perbedaan suhu antara stasiun pengukuran dengan yang dianalisis $\left({ }^{\circ} \mathrm{C}\right)$

$z_{1}=$ Elevasi stasiun pengukuran suhu $(\mathrm{m})$

$z_{2}=$ Elevasi stasiun yang dianalisis $(\mathrm{m})$

\subsubsection{Evapotranspirasi Potensial (PE)}

Nilai evapotranspirasi potensial dihitung menggunakan metode Thornthwaite-Matter melalui persamaan:

$$
\begin{aligned}
& i=(T / 5)^{1.514} \\
& P E=f . P E x \text { dengan nilai, } P E x=16(10 T / I)^{a}
\end{aligned}
$$


di mana:

PEx : Evapotranspirasi Potensial (mm/bulan)

$f \quad$ : Faktor koreksi lintang dan waktu

$T \quad$ : Suhu udara $\left({ }^{\circ} \mathrm{C}\right)$

$I \quad$ : Jumlah indeks panas dalam setahun

$a \quad:$ indeks panas, $a=\left(0.675 \cdot 10^{-6} . I^{3}\right)\left(0.77 \cdot 10^{-4} . I^{2}\right)+0.01792 . I+0.49239$

\subsubsection{Neraca Air}

Neraca air (water balance) merupakan suatu analisis yang menggambarkan pemanfaatan sumber daya air di suatu daerah didasarkan pada perbandingan antara kebutuhan dan ketersediaan air. Pembukaan lahan untuk pembangunan infrastruktur dan permukiman yang tidak terkendali secara tidak langsung berdampak terhadap timbulnya masalah banjir dan berkurangnya daerah resapan. (Bonita dan Mardyanto, 2015). Hasil akhir perhitungan neraca air secara umum diperoleh dari selisih antara curah hujan $(P)$ dengan nilai $E P$, sehingga didapatkan kelebihan dan kekurangan air pada periode basah atau kering. Apabila jumlah kumulatif curah hujan $(P)$ yang dinyatakan dalam $\mathrm{mm}$ lebih besar dibanding nilai evapotranspirasi potensial $(P E)$ maka analisis neraca air menunjukkan nilai positif atau dengan kata lain terjadi surplus di wilayah tersebut, artinya jumlah kelebihan air yang tersedia selama periode tertentu dalam satu tahun yang dapat digunakan untuk mengembalikan kelembaban tanah dan aliran permukaan. Secara matematis analisis neraca air dapat ditulis:

$$
\Delta s=P-P E
$$

$\Delta s<0, P<P E$, maka terjadi defisit

$\Delta s>0, P>P E$, maka terjadi surplus

Apabila jumlah kumulatif curah hujan $(P)$ lebih kecil dibanding nilai evapotranspirasi potensial $(P E)$ maka analisis neraca air menunjukkan nilai negatif, artinya daerah tersebut mengalami defisit air, kondisi dimana jumlah $\mathrm{CH}$ yang jatuh tidak mampu menambah kebutuhan potensi air dari areal yang tertutup vegetasi (Anna dkk, 2016). Umumnya pada bulan-bulan kering atau kemarau, nilai $P<P E$ sedangkan pada periode bulan-bulan basah nilai $P>P E$.

\section{PEMBAHASAN}

\subsection{Klasifikasi Iklim Indonesia}

Iklim Indonesia rentan mendapat banyak pengaruh, baik secara global, regional, maupun lokal. Ketiga pengaruh tersebut kemudian menunjukkan 3 pola umum tipe hujan di Indonesia, yaitu pola monsunal, pola ekuatorial, dan pola lokal. Lebih lanjut, Aldrian dan Susanto (2003) membagi wilayah-wilayah tipe iklim berdasar pola hujan ke dalam tiga kelompok, yaitu wilayah $\mathrm{A}$, wilayah $\mathrm{B}$, dan wilayah $\mathrm{C}$. Wilayah A merupakan wilayah-wilayah dengan pola iklim monsunal, wilayah B merupakan wilayah-wilayah dengan pola iklim ekuatorial, sedangkan wilayah $\mathrm{C}$ merupakan wilayah-wilayah dengan pola iklim lokal.

Wilayah A terletak di selatan Indonesia mulai dari Sumatera Selatan sampai ke pulau Timor, Kalimantan bagian selatan, Sulawesi dan sebagian dari Irian Jaya. Wilayah B terletak di barat laut Indonesia dari Sumatera bagian utara sampai Kalimantan barat laut. Wilayah C meliputi Maluku dan Sulawesi Utara. Ketiga Wilayah ini menunjukkan variabilitas tahunan dan, kecuali wilayah A, variabilitas setengah tahunan yang kuat. Wilayah C merupakan wilayah yang mendapatkan pengaruh El Nino Southern Oscillation (ENSO) paling kuat, 
kemudian diikuti oleh Wilayah A. Sedangkan pada Wilayah B, sinyal dan pengaruh ENSO cenderung dapat ditekan.

Wilayah A memiliki satu puncak dan satu palung dan mendapat pengaruh kuat akibat pergantian angin monsun, yaitu monsun barat laut yang lembab dari bulan November sampai Maret (NDJFM) dan monsun tenggara yang kering dari bulan Mei sampai September (MJJAS). Wilayah B memiliki dua puncak, pada bulan Oktober-November (ON) dan pada bulan Maret sampai Mei (MAM). Kedua puncak tersebut terkait dengan pergerakan selatan dan utara dari zona konvergensi antar-tropis (ITCZ).

Berdasarkan pembagian tersebut dapat diketahui juga bahwa domain lokasi penelitian berada dalam wilayah A yang merupakan wilayah dengan tipe hujan berpola monsun, artinya pengaruh monsun sangat kuat dalam memengaruhi variabilitas curah hujan di lokasi penelitian. Secara umum, pada daerah berpola monsun, tipe curah hujannya terdiri atas satu puncak musim hujan pada bulan Desember-Januari-Februari (DJF) dan musim kemarau pada bulan Juni-Juli-Agustus (JJA). Terkait ketersediaan sumber daya air, domain lokasi penelitian yang terletak di Pulau Jawa berpeluang besar untuk mengalami surplus pada periode bulanbulan basah, yaitu periode DJF. Sedangkan pada periode bulan-bulan kering (JJA), umumnya beberapa wilayah di Pulau Jawa mengalami kekurangan sumber daya air (defisit).

\subsection{Kondisi Curah Hujan Wilayah Penelitian}

Gambar 1 menunjukkan kondisi curah hujan di wilayah penelitian yang meliputi Bandung, Solo, dan Pasuruan. Grafik berwarna biru menunjukkan kondisi curah hujan rata-rata di wilayah Bandung yang didapatkan dari hasil pengamatan 12 titik stasiun pengamat curah hujan selama 10 tahun (2000-2009). Penurunan jumlah curah hujan mulai diamati sejak periode musim transisi I, Maret-April-Mei (MAM), dan semakin turun secara drastis pada periode bulan-bulan kering musim kemarau (JJA). Variasi nilai rata-rata curah hujan dalam periode musim kemarau (JJA) adalah paling rendah atau kecil. Sementara itu, variasi jumlah curah hujan pada periode bulan-bulan basah musim penghujan (DJF) menunjukkan nilai yang paling tinggi di ketiga wilayah penelitian. Pada periode musim transisi I (MAM), pola curah hujan cenderung menunjukkan penurunan bertahap hingga bulan Mei. Pola yang berbeda diamati pada periode musim transisi II, September-Oktober-November (SON), dimana pola curah hujan cenderung mengalami kenaikan, dengan puncak kenaikan terjadi pada bulan November. Curah hujan maksimum di wilayah Bandung terjadi pada November yaitu sebesar $260.0 \mathrm{~mm}$ dan curah hujan minimum terjadi pada bulan Agustus, yaitu sebesar $32.0 \mathrm{~mm}$. 


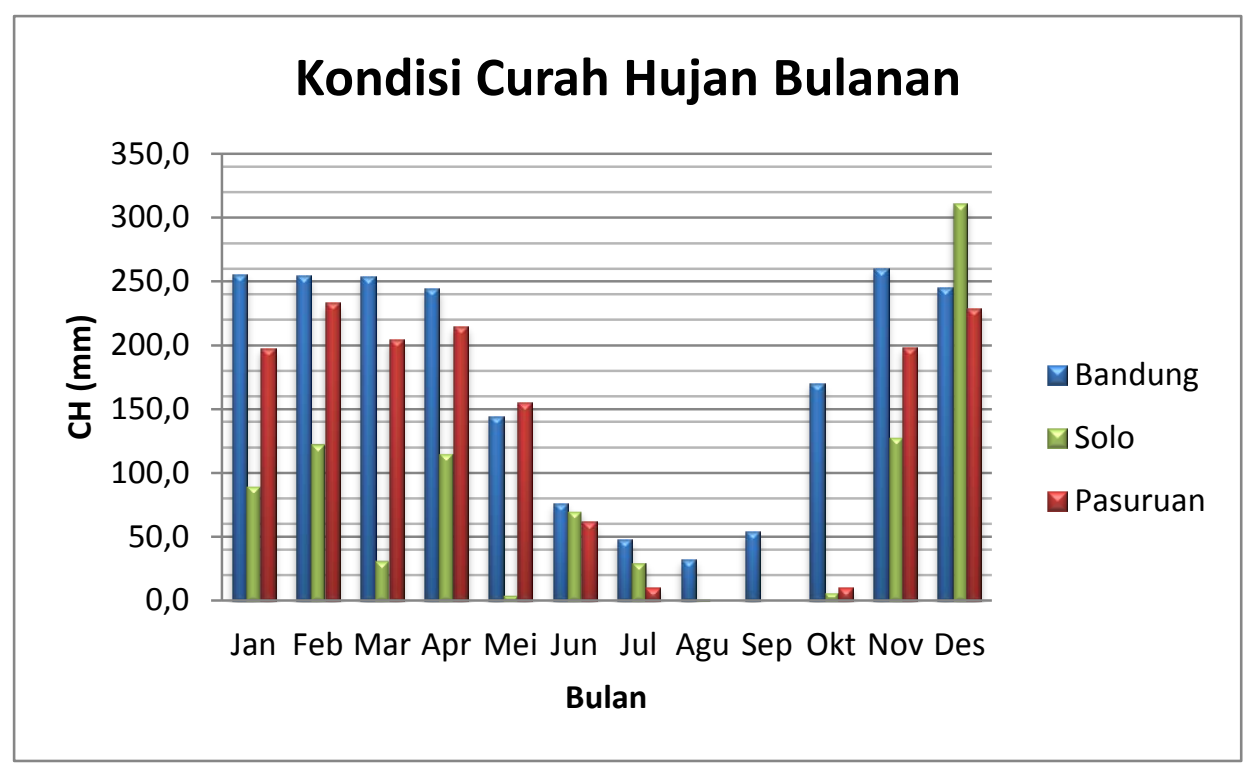

Gambar 1. Variabilitas curah hujan rata-rata bulanan di wilayah Bandung, Solo, dan Pasuruan

Secara umum nilai rata-rata curah hujan bulanan di daerah DAS Bengawan Solo lebih rendah dibandingkan dengan daerah lainnya. Pada periode musim transisi I (MAM), pola curah hujan cenderung tidak stabil di mana jumlah curah hujan cukup tinggi pada bulan April namun kembali turun dengan sangat tajam pada bulan Mei. Pola yang berbeda dapat diamati pada periode musim transisi II (SON), di mana pola curah hujan cenderung mengalami kenaikan dibanding jumlah curah hujan pada bulan September yang bernilai $0 \mathrm{~mm}$. Peningkatan jumlah curah hujan yang sangat signifikan terjadi pada bulan November yaitu mencapai $128.5 \mathrm{~mm}$ dan mencapai puncaknya (maksimum) pada Desember, yaitu mencapai $311.0 \mathrm{~mm}$. Periode curah hujan maksimum bersesuaian dengan puncak periode musim penghujan di bulan Desember, sedangkan jumlah minimumnya bersesuaian dengan sedang giatnya aktivitas monsun Australia pada bulan-bulan kering JJA dan awal musim transisi pada bulan September.

Periode pengamatan curah hujan di wilayah Pasuruan sendiri didapatkan dari hasil pengamatan pada tahun 2014 (Bonita dan Mardyanto, 2015). Pada periode musim transisi I (MAM), pola curah hujan menunjukkan pola yang kurang jelas, di mana jumlah curah hujan turun pada bulan April namun kembali mengalami kenaikan pada bulan Mei. Pola yang berbeda diamati pada periode musim transisi II (SON), di mana pola curah hujan cenderung mengalami kenaikan yang sangat signifikan pada bulan November, yaitu mencapai 198,33 mm. Curah hujan bulanan maksimum di wilayah Pasuruan terjadi pada Desember, yaitu mencapai $229.0 \mathrm{~mm}$ dan curah hujan minimumnya terjadi pada Agustus dan September, yaitu $0.0 \mathrm{~mm}$. Berdasarkan data grafik di atas dapat diketahui juga bahwa curah hujan maksimum di ketiga wilayah penelitian tersebut umumnya terjadi di bulan November atau Desember sedangkan curah hujan minimum terjadi di bulan Agustus yang bersesuaian dengan puncak periode musim kemarau pada periode tersebut. 


\subsection{Ketersediaan Sumber Daya Air di Pulau Jawa}

\subsubsection{Profil Ketersediaan Air di Bandung}

Berdasarkan hasil perhitungan neraca air menggunakan metode Thornthwaite Mather yang dilakukan oleh Fu'adah dkk (2015), dapat diketahui bahwa pada umumnya Bandung mengalami defisit air pada musim kemarau, utamanya pada bulan Juni sampai September. Defisit paling besar terjadi di daerah Cileunyi, Dago, dan Padalarang yang disebabkan oleh nilai curah hujan $(P)$ yang jauh lebih kecil dibandingkan nilai evapotranspirasi potensial $(P E)$. Sementara itu, defisit paling kecil terjadi di stasiun Cibuni. Hal tersebut terjadi karena daerah Cibuni memiliki elevasi yang tinggi dan curah hujan yang tinggi. Memasuki bulan Juli daerah Cileunyi, Dago, dan Padalarang mengalami penurunan ketersediaan air tanah ditunjukkan dengan warna orange yang berarti bahwa di wilayah tersebut jumlah ketersediaan air tanah terbilang sedang (Gambar 3a). Pada bulan Agustus, ketiga daerah tersebut menunjukkan ketersediaan air yang semakin berkurang sedangkan di daerah Cibuni masih memperlihatkan ketersediaan air yang cukup (Gambar 3b).

Tabel 1. Status ketersediaan air di beberapa wilayah di Bandung, Jawa Barat

\begin{tabular}{ccc}
\hline Nama Daerah & Periode Musim Penghujan & Periode Musim Kemarau \\
\hline Cileunyi & SURPLUS & DEFISIT \\
Dago & SURPLUS & DEFISIT \\
Padalarang & SURPLUS & DEFISIT \\
Cibuni & SURPLUS & DEFISIT
\end{tabular}

Peta spasial ketersediaan air pada bulan September menujukkan hampir setengah wilayah Bandung mengalami defisit air, kecuali daerah Cibuni yang masih memiliki nilai ketersediaan air yang cukup (Gambar 3c). Sementara itu, peningkatan ketersediaan air cukup signifikan kembali pada bulan Oktober (Gambar 3d). Hampir sebagian besar wilayah Bandung berada dalam kondisi ketercukupan jumlah air (surplus), hanya daerah Dago dan Padalarang yang nilai ketersediaan airnya kurang. Pada bulan-bulan sisanya yaitu pada bulan Januari-Mei dan November-Desember seluruh wilayah Bandung memperlihatkan bahwa nilai ketersediaan airnya cukup atau mengalami surplus. Berdasarkan rata-rata bulanan curah hujan pada Grafik 1, wilayah Bandung mengalami defisit ketersediaan air karena pada bulan Juni-September bersamaan dengan datangnya periode bulan-bulan kering/musim kemarau dan awal dari periode transisi II, dengan puncak defisit ketersediaan airnya terjadi pada bulan September. 

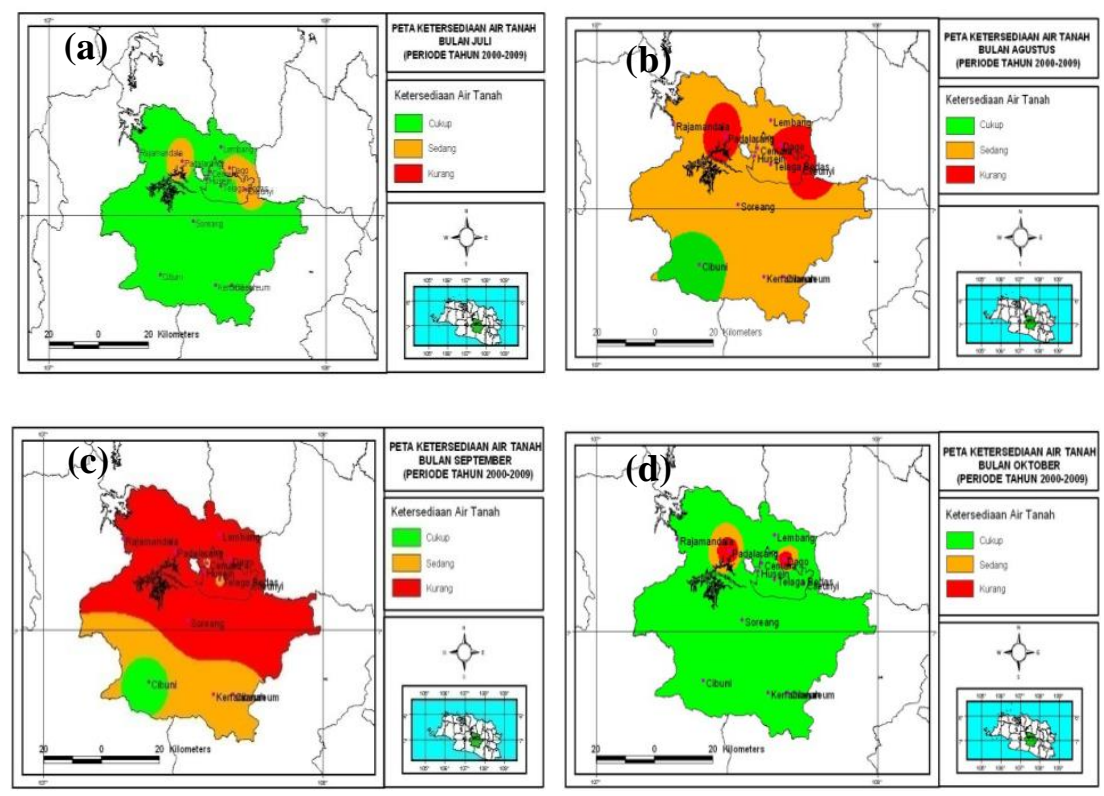

Gambar 2. Peta spasial ketersediaan sumber daya air tanah di Bandung pada bulan (a) Juli, (b) Agustus, (c) September, dan (d)

Oktober (Fu'adah dkk, 2015).

\subsubsection{Profil Ketersediaan Air di Solo}

Berdasarkan perhitungan neraca air di DAS Begawan Solo, surplus air terjadi di sub-sub DAS Bambang, Dengkeng, Jlantah Walikun Ds, Keduang, Mungkung, Pepe, dan Samin. Defisit air terjadi di sub-sub DAS Alang Unggahan, dan Wiroko Temon. Hasil ini didapatkan dari perhitungan curah hujan dengan luas wilayah sub-sub DAS Begawan Solo Hulu sehingga nantinya didapatkan jumlah ketersediaan air dalam satuan liter $/ \mathrm{dm}^{3}$ dengan metode poligon thiessen. Daerah penelitian memiliki ketersediaan air antara 37.459,80-142.892,59 liter/ $\mathrm{dm}^{3}$. Sementara kebutuhan air di daerah penelitian sendiri berkisar antara 50.782.500 - 131.690.700 liter/ $\mathrm{dm}^{3}$. Tingkat kekritisan air dihitung dengan indeks kekritisan air $(I K)$ yang dirumuskan oleh persamaan berikut ini:

$$
I K=\text { Kebutuhan air/Ketersediaan air x } 100 \%
$$

Berdasarkan perhitungan IK, tingkat kekritisan air di daerah penelitian berkisar antara $344,6 \%$ sampai 921,6\%. Jika hasil dari perhitungan tersebut angka $I K$ mencapai lebih dari $100 \%$, bisa dikatakan bahwa daerah tersebut mengalami kekeringan kategori sangat kritis karena ketersediaan air tidak mampu memenuhi kebutuhan airnya. Kriteria lebih lanjut terkait penentuan batas indeks kekritisan air ditampilkan dalam tabel 2 berikut:

Tabel 2. Klasifikasi kekritisan ketersediaan sumber daya air

\begin{tabular}{lcc}
\hline No & Kelas Kekritisan (\%) & Keterangan \\
\hline 1 & $<50$ & Tidak kritis \\
2 & $50-75$ & Cukup kritis \\
3 & $76-100$ & Kritis \\
4 & $>100$ & Sangat kritis \\
\hline
\end{tabular}

Berdasarkan hasil perhitungan metode neraca air serta indeks kekeringan menunjukkan jika ketersediaan air di wilayah DAS Bengawan Solo mengalami defisit (Tabel 3). 
Tabel 3. Neraca air DAS Begawan Solo

\begin{tabular}{cccc}
\hline Daerah & $\begin{array}{c}\text { Ketersediaan } \\
\text { Air Total (L) }\end{array}$ & $\begin{array}{c}\text { Kebutuhan Air } \\
\text { Total (L) }\end{array}$ & Keterangan \\
\hline $\begin{array}{c}\text { Kabupaten } \\
\text { Sukoharjo }\end{array}$ & $138.275,6$ & 84.950 .600 & Defisit \\
Kabupaten & $157.778,5$ & 84.017 .100 & Defisit \\
Karanganyar & 116.506 & 50.782 .500 & Defisit \\
$\begin{array}{c}\text { Kota Surakarta } \\
\text { Kabupaten } \\
\text { Boyolali }\end{array}$ & 116.506 & 96.383 .900 & Defisit \\
$\begin{array}{c}\text { Kabupaten Klaten } \\
\text { Kabupaten } \\
\text { Wonogiri }\end{array}$ & $142.892,59$ & 131.690 .700 & Defisit \\
& $273.434,5$ & 94.237 .700 & Defisit \\
\hline
\end{tabular}

\subsubsection{Profil Ketersediaan Air di Pasuruan}

Ketersediaan air di Kecamatan Kejayan Kabupaten Pasuruan terhitung masih mencukupi pada tahun 2014. Hal tersebut dapat dilihat dari hasil perhitungan neraca air pada tabel 4 di bawah ini. Dari tabel neraca air tersebut dapat diketahui bahwa pada musim kemarau terjadi defisit yang cukup signifikan namun hal itu diimbangi dengan surplus yang terjadi cukup besar di musim hujan sehingga selama tahun 2014 neraca air di Kabupaten Pasuruan mengalami surplus.

Tabel 4. Neraca air di Kabupaten Pasuruan tahun 2014

\begin{tabular}{cccc}
\hline Musim & $\begin{array}{c}\text { Ketersediaan Air } \\
\left(\mathbf{m}^{\mathbf{3}}\right)\end{array}$ & $\begin{array}{c}\text { Kebutuhan Air } \\
\left(\mathbf{( m}^{\mathbf{3}} \mathbf{)}\right.\end{array}$ & Keterangan \\
\hline Hujan & 52.097 .845 & 19.592 .307 & Surplus \\
Kemarau & 1.411 .617 & 13.994 .505 & Defisit \\
Total & 53.509 .462 & 33.586 .808 & \\
\hline
\end{tabular}

Berpijak pada hasil analisis neraca air di atas, Bonita dan Mardyanto (2015) juga menggunakan datanya untuk memproyeksikan ketersediaan sumber daya air hingga tahun 2023 dengan asumsi penggunaan air domestik selalu meningkat setiap tahunnya. Sehingga didapatkan hasil evaluasi perhitungan neraca air pada tahun 2008-2023 masih tidak defisit atau surplus. Hasilnya, jumlah akuifer bebas yang ditinjau pada penelitian ini masih mampu memenuhi kebutuhan air tanah Kecamatan Kejayan hingga tahun 2023 (Tabel 5), walaupun masih terdapat bulan-bulan yang mengalami kekurangan air dikarenakan saat musim kemarau maka dari itu diperlukan adanya upaya menjaga kuantitas air agar tidak terjadi kekurangan air pada bulan-bulan tertentu disetiap tahunnya. Dapat digambarkan pada grafik yang terdapat di tabel 5 .

Tabel 5. Hasil perhitungan $\Delta S$ tahun 2008 sampai tahun 2023

\begin{tabular}{|c|c|c|c|c|c|c|c|c|}
\hline Tahun & $\begin{array}{c}\mathbf{P} \\
(\mathbf{m m} / \text { tahun } \\
)\end{array}$ & $\begin{array}{c}\mathrm{PE} \\
(\mathrm{mm} / \mathrm{tah} \\
\mathrm{un})\end{array}$ & $\begin{array}{c}\mathrm{A} \\
(\mathrm{km} 2)\end{array}$ & Cro & $\begin{array}{c}\mathbf{R} \\
\text { (m3/tahun) }\end{array}$ & $\begin{array}{c}\text { Q out } \\
\text { (m3/tahun) }\end{array}$ & $\begin{array}{c}\text { Neraca } \\
\text { (m3/tahun) }\end{array}$ & Keterangan \\
\hline 2008 & 1513.6667 & 8.77 & 79.15 & 0.52 & 53.509 .462 & 21.596 .520 & 31.912 .942 & Surplus \\
\hline 2009 & 1513.6667 & 8.77 & 79.15 & 0.52 & 53.509 .462 & 21.806 .140 & 31.703 .322 & Surplus \\
\hline 2010 & 1513.6667 & 8.77 & 79.15 & 0.52 & 53.509 .462 & 22.010 .955 & 31.498 .507 & Surplus \\
\hline 2011 & 1513.6667 & 8.77 & 79.15 & 0.52 & 53.509 .462 & 23.856 .961 & 29.652 .501 & Surplus \\
\hline 2012 & 1513.6667 & 8.77 & 79.15 & 0.52 & 53.509 .462 & 25.917 .651 & 27.591 .811 & Surplus \\
\hline
\end{tabular}




\begin{tabular}{lllllllll}
2013 & 1513.6667 & 8.77 & 79.15 & 0.52 & 53.509 .462 & 29.738 .677 & 23.770 .785 & Surplus \\
2014 & 1513.6667 & 8.77 & 79.15 & 0.52 & 53.509 .462 & 33.586 .808 & 19.922 .654 & Surplus \\
2015 & 1513.6667 & 8.77 & 79.15 & 0.52 & 53.509 .462 & 33.727 .242 & 19.782 .220 & Surplus \\
2016 & 1513.6667 & 8.77 & 79.15 & 0.52 & 53.509 .462 & 33.937 .029 & 19.572 .433 & Surplus \\
2017 & 1513.6667 & 8.77 & 79.15 & 0.52 & 53.509 .462 & 34.056 .327 & 19.453 .135 & Surplus \\
2018 & 1513.6667 & 8.77 & 79.15 & 0.52 & 53.509 .462 & 34.153 .186 & 19.356 .276 & Surplus \\
2019 & 1513.6667 & 8.77 & 79.15 & 0.52 & 53.509 .462 & 38.155 .009 & 15.354 .453 & Surplus \\
2020 & 1513.6667 & 8.77 & 79.15 & 0.52 & 53.509 .462 & 37.823 .237 & 15.686 .225 & Surplus \\
2021 & 1513.6667 & 8.77 & 79.15 & 0.52 & 53.509 .462 & 38.013 .028 & 15.496 .434 & Surplus \\
2022 & 1513.6667 & 8.77 & 79.15 & 0.52 & 53.509 .462 & 38.332 .681 & 15.176 .781 & Surplus \\
2023 & 1513.6667 & 8.77 & 79.15 & 0.52 & 53.509 .462 & 42.883 .714 & 10.625 .748 & Surplus \\
\hline
\end{tabular}

\subsubsection{Proyeksi Ketersediaan Air}

Selain dilakukan proyeksi di daerah Pasuruan, Anna dkk (2016) juga melakukan proyeksi ketersediaan sumber daya air pada DAS Begawan Solo Hulu, dimana tingkat kebutuhan air saat ini di daerah penelitian terletak antara 50.782.500 - 131.690.700 dan proyeksi 5 tahun ke depan hingga tahun 2018, kebutuhan air di daerah penelitian diperkirakan mencapai 544.510.800 - 5.264.009.700 liter. Artinya terjadi peningkatan kebutuhan sumber daya air secara signifikan di tahun 2018. Setelah dikaji oleh Anna dkk (2016), hal tersebut disebabkan oleh peningkatan jumlah penduduk. Semakin besar jumlah penduduk, maka semakin besar pula kebutuhan akan air. Adapun konsekuensi yang bisa ditimbulkan dari tingkat kekritisan air meteorologis ini adalah timbulnya bencana kekeringan wilayah. Selain itu dampak yang timbul adalah minimnya cadangan air tanah di daerah kajian. Salah satu pilihan yang bisa dilakukan untuk meminimalisir dampak tersebut adalah dengan melakukan konservasi air tanah, sehingga apabila mengalami masuk musim kemarau cadangan air tanah bisa dimanfaatkan. Sementara di daerah Pasuruan, potensi sumber daya air tanah cukup tinggi (mengalami surplus) sehingga mampu memenuhi kebutuhan air tanah hingga tahun 2023 seperti yang ditunjukkan pada tabel 5. Perhitungan neraca air menggunakan metode Thornwaite Mather serta metode Ffoliot menunjukkan bahwa tidak terjadi defisit.

\section{KESIMPULAN}

Curah hujan maksimum di ketiga wilayah penelitian umumnya terjadi di bulan November atau Desember yang bersesuaian dengan periode bulan-bulan basah/musim penghujan akibat pengaruh angin monsun barat laut yang bersifat lembap. Curah hujan minimum terjadi pada bulan Agustus yang bersesuaian dengan puncak periode musim kemarau pada periode JJA yang terjadi akibat pengaruh angin monsun tenggara yang bersifat kering. Lebih lanjut, hasil evaluasi ketersediaan sumber daya air di Bandung menunjukkan kondisi surplus air pada periode musim penghujan dan defisit pada periode musim kemarau. Sementara itu, analisis neraca air di wilayah DAS Bengawan Solo menunjukkan kondisi defisit pada seluruh area DAS. Analisis neraca air menggunakan metode Thornthwaite Mather di Kabupaten Pasuruan menunjukkan pola yang sama dengan wilayah Bandung, dimana terjadi kondisi surplus pada periode musim penghujan dan defisit pada periode musim kemarau. Hasil proyeksi ketersediaan sumber daya air menunjukkan jika wilayah Bandung umumnya akan mengalami defisit air tanah pada bulan Juni-September dan surplus pada bulan Oktober-Januari. Proyeksi tingkat kebutuhan air di DAS Bengawan Solo dari waktu penelitian hingga pada 5 tahun ke depan atau tahun 2018 menyebutkan bahwa kebutuhan air meningkat secara signifikan antara 544.510.800 - 5.264.009.700-liter sehingga wilayah-wilayah pada DAS tersebut terancam mengalami defisit yang sangat kritis. Hal yang berbeda, ditunjukkan melalui hasil proyeksi 
daerah Pasuruan yang menunjukkan tingginya potensi ketersediaan sumber daya air tanah hingga tahun 2023. Perhitungan neraca air menggunakan metode Thornwaite serta metode Ffoliot juga tidak menunjukkan terjadinya defisit pada tiap tahunnya hingga tahun 2023

\section{DAFTAR PUSTAKA}

Aldrian, E. dan Susanto, R. D. 2003. Identification of three dominant rainfall Wilayahs within Indonesia and their relationship to sea surface temperature. Int. J. of Climatol. 23: $1435-1452$.

Anna, A.N., Priyono, K.D., Suharjo, dan Priyana, Y. 2016. Neraca sumber daya wilayah dan kekritisan air meteorologi DAS Bengawan Solo Hulu. Universty Research Colloquium, ISSN 2407-9189.

Badan Meteorologi Klimatologi dan Geofisika. 2017. Prakiraan musim penghujan dan kemarau. Jakarta: BMKG

Bonita, R. dan Mardyanto, M. A. 2015. Studi water balance air tanah di kecamatan Kejayan Kabupaten Pasuruan Jawa Timur. J. Teknik ITS Vol. 4 No. 1, ISSN 2337-3539 (2301-9271 Printed).

Calvo, J.C. 1986. An Evaluation of Thornthwaite's water balance technique on prediction of surface runoff in Costa Rika. Departemen de Ingeniera Forestal, Institute Tecnologico de Costa Rica Apartado 159, Cartago, Costa Rica.

Fu'adah, A.T., Iryanti, M., dan Mujtahiddin, M.I. 2015. Analisa spasial ketersediaan air tanah di wilayah Bandung dengan menggunakan metode neraca air Thornthwaite Mather. Fibusi (J. Online Fisika) Vol. 3 No. 1.

Mawardi, I. 2010. Kerusakan daerah aliran sungai dan penurunan daya dukung sumber daya air di Pulau Jawa serta upaya penanganannya. J. Hidrosfer Indonesia, Vol 5 No. 2: 1 -11 .

Mock, F. J. 1973. Land capability apprassial Indonesia, water available apprassial. FAO/UNDP. Working Paper No. 1. Bogor. Indonesia

Nasution, C.H. dan Syaifullah, D. (2005). Analisis spasial indeks kekeringan daerah Pantai Utara (Pantura) Jawa Barat. J. Akuakultur Indonesia Vol 1 No. 2 2005, UPTHBBPPT.

Pramono, I. B., dan Adi, R. N. 2010. Perbandingan hasil estimasi potensi air bulanan dan hasil pengukuran langsung di sub DAS Wuryantoro, Wonogiri. J. Penelitian Hutan dan Konservasi Alam Vol 7 No. 2 :127-137.

Prastowo, et 01. 2007. Kojian Daya Dukung Lingkungan Daerah Aliran Sungai. Paper: "Workshop Daya Dukung Lingkungan". Kementerian Lingkungan Hidup - RI. Jakarta, 9 Agustus 2007.

Prastowo. 2010. Daya dukung lingkungan aspek sumber daya air. Pusat Pengkajian Perencanaan dan Pengembangan Wilayah (P4W). Working paper No. 1, November 2010. Bogor: IPB

Republik Indonesia. 2007. Undang-Undang No. 26 Tahun 2007 Tentang Penataan Ruang. Sekretariat Kabinet RI. Jakarta. 
Republik Indonesia. 2009. Undang-Undang No. 32 Tahun 2009 Tentang Pengelolaan Lingkungan Hidup. Sekretariat Kabinet RI. Jakarta.

Thornthwaite, C.W. and J.R. Mather. 1957. Instruction and Tables for Computing Evapotranspiration and Water Balance. Publication in Cli-matology. Drexel Institute of Tech-nology, Laboratory of Climatology. New Jersey: Certerton.

Triatmodjo, B. 2008. Hidrologi Terapan. Yogyakarta: Beta Offset Yogyakarta. 